ISSN 0258-7122 (Print), 2408-8293 (Online)

Bangladesh J. Agril. Res. 44(1): 13-26, March 2019

\title{
INTEGRATED NUTRIENT MANAGEMENT FOR GROWTH, YIELD AND PROFITABILITY OF BROCCOLI
}

\author{
E. KAYESH ${ }^{1}$, M. S. SHARKER ${ }^{2}$, M. S. RONI ${ }^{3}$ AND U. SARKER ${ }^{4}$
}

\begin{abstract}
A field experiment on broccoli taking the hybrid variety 'Green Magic' was conducted with seven treatments $\left[\mathrm{T}_{1}=100 \%\right.$ recommended dose of inorganic fertilizer(100-35-60-18-2-1.2 kg/ha of N-P-K-S-Zn-B+Cowdung (CD) @5 t/ha), $\mathrm{T}_{2}=50 \%$ inorganic fertilizer recommended dose + Mustard Oil Cake(MOC) @ $1.5 \mathrm{t} / \mathrm{ha}, \mathrm{T}_{3}=50 \%$ inorganic fertilizer of recommended dose + CD @ $10 \mathrm{t} / \mathrm{ha}, \mathrm{T}_{4}$ $=50 \%$ inorganic fertilizer of recommended dose + Poultry Manure (PM) @ 6 $\mathrm{t} / \mathrm{ha}, \mathrm{T}_{5}=25 \%$ inorganic fertilizer of recommended dose $+\mathrm{MOC} @ 3 \mathrm{t} / \mathrm{ha}, \mathrm{T}_{6}=$ $25 \%$ inorganic fertilizer of recommended dose + CD @ $15 \mathrm{t} / \mathrm{ha}, \mathrm{T}_{7}=25 \%$ inorganic fertilizer of recommended dose + PM @ $12 \mathrm{t} / \mathrm{ha}$ ] at the Horticultural Research Farm of Bangabandhu Sheikh Mujibur Rahman Agricultural University, Salna, Gazipur during the period from September 2015 to February 2016. The aim of the study was to standardize the organic manure and inorganic fertilizers of broccoli for proper growth and yield. The experiment was laid out in a Randomized Complete Block Deign with three replications. All the parameters studied were significantly influenced by different treatments. The maximum plant height $(62.20 \mathrm{~cm})$ and canopy spread $(64.67 \mathrm{~cm})$, maximum number of leaves/plant $(30.23)$ and average size of leaves $\left(738.1 \mathrm{~cm}^{2}\right)$ and length of terminal head $(15.57 \mathrm{~cm})$ were found in $T_{5}$ which was statistically similar with $\mathrm{T}_{7}$. The diameter of stems $(3.87 \mathrm{~cm})$, terminal head diameter $(16.17$ $\mathrm{cm})$, terminal head weight/plant (424.6 g), number of lateral heads/plant (4.86), weight of lateral heads/plant $(155.5 \mathrm{~g})$, yield/plot $\left(11.60 \mathrm{~kg} / 6 \mathrm{~m}^{2}\right)$, yield $(19.34$ $\mathrm{t} / \mathrm{ha}$ ) were found the highest in $\mathrm{T}_{7}$ which was statistically similar with $\mathrm{T}_{5}$. Gross return and net return were the highest in $\mathrm{T}_{7}$ and benefit cost ratio (BCR) was also maximum (3.64) in $\mathrm{T}_{7}$.
\end{abstract}

Keywords: Organic fertilizer, Inorganic fertilizer, Growth, Yield and Broccoli.

\section{Introduction}

Broccoli (Brassica oleraceavar. italica L.) is one of the non-traditional and relatively new cole crops in Bangladesh, belonging to the family Brassicaceae and it is grown in cool winter season in Bangladesh as an annual crop (Swarup, 2012).

Broccoli responds greatly to major essential elements like $\mathrm{N}, \mathrm{P}$, and $\mathrm{K}$ in respect of its growth and yield (Mital et al., 1975; Singh et al., 1976; Thompson and

\footnotetext{
${ }^{1-3}$ Department of Horticulture, ${ }^{4}$ Department of Genetics and Plant Breeding, Bangabandhu Sheikh Mujibur Rahman Agricultural University (BSMRAU), Gazipur, Bangladesh.
} 
Kelly, 1988) and storage life. Nutrients may be applied through two sources viz., organic and inorganic. Increased use of chemical fertilizers in crop field causes health hazards, and create problem to the environment by polluting water, air and soil. The continuous use of chemical fertilizers also badly affects the soil texture and structure. Decreased organic matter content of soil hampers soil microbial activity. Soils of Bangladesh contain 0.056 to $1.638 \%$ organic matter (Akter et al., 2012). Now a days gradual decrease of soil organic matter and reduced yield of crop are alarming issues to the farmers. Organic manure plays direct role in plant growth as a source of all necessary macro and micronutrients in available forms during mineralization and improves physical and chemical properties of soils (Chaterjee et al., 2005, Kumaret al., 2013, Attigah et al., 2013).

Cow dung, poultry manure and mustard oil cake are available in the country, which are the good source of all the essential nutrients. Use of these manures also improves the organic matter status of soil. A judicious application of organic and inorganic fertilizers might be helpful to obtain a good economic return from a crop, as well as from the subsequent crop, and to maintain good soil health (Abou El- Magd et al., 2006).

The production technology of broccoli has not yet been standardized in Bangladesh. Available information is scanty regarding the effect of organic manure with inorganic fertilizers on the growth and yield of broccoli. The present study was undertaken to investigate vegetative growth and yield performance of broccoli under different doses of organic manure and inorganic fertilizer and to find out the best combinations of them for sustainable crop productivity.

\section{Materials and Methods}

An experiment on integrated nutrient management of broccoli was conducted at the Horticultural Research Farm of Bangabandhu Sheikh Mujibur Rahman Agricultural University (BSMRAU), Gazipur during the period from September 2015 to February 2016. The variety of broccoli used in this experiment was Green Magic, a hybrid, which was produced by Sakata Co. Ltd., Japan. The seeds were collected from Siddique Bazar of Dhaka. The experiment comprised of seven treatments $\left[\mathrm{T}_{1}=100 \%\right.$ Recommended Dose of Fertilizer (RDF) (10035-60-18-2-1.2 kg/ha of N-P-K-S-Zn-B+Cowdung (CD) @ $5 \mathrm{t} / \mathrm{ha}$ ), $\mathrm{T}_{2}=50 \%$ RDF + Mustard Oil Cake (MOC) @ $1.5 \mathrm{t} / \mathrm{ha}, \mathrm{T}_{3}=50 \% \mathrm{RDF}+\mathrm{CD} @ 10 \mathrm{t} / \mathrm{ha}, \mathrm{T}_{4}$ =50\% RDF + Poultry Manure (PM) @6 t/ha, $\mathrm{T}_{5}=25 \% \mathrm{RDF}+\mathrm{MOC} @ 3 \mathrm{t} / \mathrm{ha}$, $\left.\mathrm{T}_{6}=25 \% \mathrm{RDF}+\mathrm{CD} @ 15 \mathrm{t} / \mathrm{ha}, \mathrm{T}_{7}=25 \% \mathrm{RDF}+\mathrm{PM} @ 12 \mathrm{t} / \mathrm{ha}\right]$. As per treatment of the experiment, organic manures viz., cowdung, mustard oil cake and poultry manure and inorganic fertilizers viz., $\mathrm{N}$ in the form of urea, $\mathrm{P}$ in the form of triple super phosphate (TSP), $\mathrm{K}$ in the form of muriate of potash (MoP), $\mathrm{S}$ in the form of gypsum, $\mathrm{Zn}$ in the form of zinc sulphate and $\mathrm{B}$ in the form of boric acid were applied to the field. Well decomposed CD, MOC \& PM and TSP were incorporated in the soil during final land preparation. Gypsum, Ziinc 
sulphate and Boric acid were incorporate in the soil during bed preparation. Urea and MoP were applied in three instalments; the first instalment was applied 15 days after transplanting (DAT), second and third instalments were top dressed at 30 and 45 DAT. The average monthly maximum and minimum temperature, relative humidity and monthly total rainfall during the crop growing period were collected from the meteorological station of BSMRAU and are presented in Appendix-3.

The experiment was laid out in a Randomized Complete Block Design (RCBD) with three replications. Unit plot size was $2.4 \mathrm{~m} \times 2.5 \mathrm{~m}$ and 55 days old seedlings were transplanted on 22 November 2015 maintaining plant spacing of $50 \mathrm{~cm} \times 60 \mathrm{~cm}$. Intercultural operations such as weeding, mulching with straw and irrigation were done as per requirement. Data were recorded from 10 randomly selected plants of each plot on plant height $(\mathrm{cm})$, number of leaves/plant, canopy spread $(\mathrm{cm})$, stem diameter $(\mathrm{mm})$, head initiation (days), leaf size $\left(\mathrm{cm}^{2}\right)$, terminal head length $(\mathrm{cm})$, terminal head diameter $(\mathrm{cm})$, terminal head weight/plant (g), number of lateral heads/plant, lateral head weight/plant $(\mathrm{g})$, yield per plot $(\mathrm{kg} / \mathrm{ha})$ and yield $(\mathrm{t} / \mathrm{ha})$. The data were statistically analyzed using MSTATC software program. Means were separated using Least Significant Difference (LSD) test at 5\% level of probability (Gomes and Gomes, 1984). Economic analysis was done in order to compare the profitability of the treatment combination and BCR was calculated using the following formula.

$\mathrm{BCR}=\frac{\text { Gross return }(\mathrm{Tk} / \mathrm{ha})}{\text { Total cost of production }}$

\section{Results and Discussion}

\section{Plant height}

Plant height was recorded at 15, 30, and 45 DAT and at harvest. The plant height at different DAT was significantly influenced by different treatments (Table 1). At 15 DAT the tallest plant $(31.30 \mathrm{~cm})$ was recorded in $\mathrm{T}_{7}$ which was identical with $\mathrm{T}_{5}(31.03 \mathrm{~cm})$ and $\mathrm{T}_{6}(30.33 \mathrm{~cm})$. The plants of $\mathrm{T}_{2}$ showed the lowest plant height $(22.13 \mathrm{~cm})$. At $30 \mathrm{DAT}$, maximum plant height was recorded from $\mathrm{T}_{5}$ $(52.33 \mathrm{~cm})$ closely followed by $\mathrm{T}_{7}(52.10 \mathrm{~cm})$ and the lowest was recorded from $\mathrm{T}_{2}(37.70 \mathrm{~cm})$. At $45 \mathrm{DAT}, \mathrm{T}_{5}$ produced the highest plant height $(59.40 \mathrm{~cm})$ which was statistically similar with $\mathrm{T}_{7}(58.87 \mathrm{~cm})$ and $\mathrm{T}_{6}(56.67 \mathrm{~cm})$ and $\mathrm{T}_{2}$ gave the lowest plant height. At harvest, the tallest plant was recorded in $\mathrm{T}_{5}(62.20 \mathrm{~cm})$ which was identical with $\mathrm{T}_{7}(62.07 \mathrm{~cm}), \mathrm{T}_{6}(60.87 \mathrm{~cm}), \mathrm{T}_{1}(58.93 \mathrm{~cm})$ and $\mathrm{T}_{3}$ $(58.20 \mathrm{~cm})$. The plants of $\mathrm{T}_{2}$ gave the lowest plant height $(53.07 \mathrm{~cm})$. The increased plant height might be due to nitrogen both in inorganic and organic form which enhanced the plant height up to $92 \%$ over the control. These results are in complete agreement with those obtained by Rakesh et al. (2006) who 
showed that organic manure along with mineral fertilizers increased vegetative growth including plant height of broccoli.

Table 1. Effect of organic manure and inorganic fertilizerson plant height and number of leaves/plant of broccoli at different growth stage

\begin{tabular}{l|c|c|c|c|c|c|c|c}
\hline \multirow{2}{*}{$\begin{array}{l}\text { Treatment } \\
\text { combination }\end{array}$} & \multicolumn{4}{|c|}{ Plant height (cm) at DAT } & \multicolumn{4}{c}{ Leaves per plant at DAT } \\
\cline { 2 - 9 } & 15 & 30 & 45 & $\begin{array}{c}\text { At } \\
\text { harvest }\end{array}$ & 15 & 30 & 45 & 60 \\
\hline $\mathrm{T}_{1}$ & 27.77 & 43.97 & 53.87 & 58.93 & 11.57 & 16.37 & 21.33 & 27.40 \\
$\mathrm{~T}_{2}$ & 22.13 & 37.70 & 49.00 & 53.07 & 10.53 & 13.53 & 18.70 & 22.00 \\
$\mathrm{~T}_{3}$ & 27.03 & 41.03 & 52.53 & 58.20 & 11.30 & 15.50 & 20.73 & 27.57 \\
$\mathrm{~T}_{4}$ & 22.87 & 38.90 & 51.20 & 54.27 & 10.60 & 14.27 & 19.53 & 23.87 \\
$\mathrm{~T}_{5}$ & 31.03 & 52.33 & 59.40 & 62.20 & 13.07 & 18.70 & 25.07 & 30.23 \\
$\mathrm{~T}_{6}$ & 30.33 & 48.10 & 56.67 & 60.87 & 11.73 & 17.27 & 23.47 & 28.87 \\
$\mathrm{~T}_{7}$ & 31.30 & 52.10 & 58.87 & 62.07 & 12.63 & 18.00 & 24.87 & 29.73 \\
\hline LSD $_{0.05}$ & 2.80 & 3.70 & 4.74 & 5.22 & 0.979 & 2.51 & 2.94 & 2.34 \\
Level of & & & & & & & & \\
significance & $* *$ & $* *$ & $* *$ & $* *$ & $* *$ & $* *$ & $* *$ & $* *$ \\
CV (\%) & 5.75 & 4.65 & 4.90 & 5.01 & 4.73 & 8.72 & 7.54 & 4.86 \\
\hline
\end{tabular}

** Significant at $1 \%$ level of probability, DAT= Days after transplanting.

$\mathrm{T}_{1}=100 \% \mathrm{RDF} @ 5 \mathrm{t} / \mathrm{ha}, \mathrm{T}_{2}=50 \% \mathrm{RDF}+\mathrm{MOC} @ 1.5 \mathrm{t} / \mathrm{ha}, \mathrm{T}_{3}=50 \% \mathrm{RDF}+\mathrm{CD} @ 10$ $\mathrm{t} / \mathrm{ha}, \mathrm{T}_{4}=50 \% \mathrm{RDF}+\mathrm{PM} @ 6 \mathrm{t} / \mathrm{ha}, \mathrm{T}_{5}=25 \% \mathrm{RDF}+\mathrm{MOC} @ 3 \mathrm{t} / \mathrm{ha}, \mathrm{T}_{6}=25 \% \mathrm{RDF}+$ $\mathrm{CD} @ 15 \mathrm{t} / \mathrm{ha}, \mathrm{T}_{7}=25 \% \mathrm{RDF}+\mathrm{PM} @ 12 \mathrm{t} / \mathrm{ha}$.

\section{Number of leaves/plant}

The number of leaves per plant at different growth stages was significantly influenced by different treatments (Table 1). Number of leaves per plant was recorded at 15, 30, 45 and $60 \mathrm{DAT}$. At $15 \mathrm{DAT}$, the highest number of leaves per plant(13.07) was recorded in $T_{5}$ which was identical with $\mathrm{T}_{7}$ (12.63). The plants of $\mathrm{T}_{2}$ gave the lowest number of leaves per plant(10.53). At $30 \mathrm{DAT}$, the highest number of leaves per plant(18.70) was recorded in $\mathrm{T}_{5}$ closely followed by $\mathrm{T}_{7}$ (18.00) and $\mathrm{T}_{6}$ (17.27)and the lowest was obtained from $\mathrm{T}_{2}$ (13.53). Number of leaves/plant at 45 DAT showed similar trend of 30 DAT. At 60 DAT, maximum number of leaves per plant(30.23) was recorded in $\mathrm{T}_{5}$ which was identical with $\mathrm{T}_{7}$ (29.73) and $\mathrm{T}_{6}$ (28.87). The plants of $\mathrm{T}_{2}$ produced the lowest number of leaves(22.00). Rakesh et al. (2006) reported that organic manure plus mineral fertilizer enhanced the vegetative growth of broccoli plants.

\section{Stem diameter}

The diameter of stem was measured at the point where the terminal head was cut off. The diameter of stem was significantly influenced by different treatments 
(Table 2). Stem diameter was recorded at60 DAT. The maximum diameter $(3.87$ $\mathrm{cm})$ was recorded in $\mathrm{T}_{7}$ which was statistically similar with $\mathrm{T}_{5}(3.86 \mathrm{~cm})$ and $\mathrm{T}_{6}$ $(3.72 \mathrm{~cm})$. The minimum stem diameter $(3.26 \mathrm{~cm})$ was noted in $\mathrm{T}_{2}$. The diameter of stem was found maximum might be due to enjoying optimum nutrients at early stage (Rabby, 2008).

Table 2. Effect of organic manure and inorganic fertilizer on canopy spread, stem diameter and head initiationof broccoli

\begin{tabular}{c|c|c|c|c}
\hline \multirow{2}{*}{$\begin{array}{c}\text { Treatment } \\
\text { combination }\end{array}$} & $\begin{array}{c}\text { Stem diameter } \\
(\mathrm{cm})\end{array}$ & $1 \mathrm{st}$ & $50 \%$ & $100 \%$ \\
\cline { 3 - 5 } & 3.55 & 37.67 & 45.00 & 52.33 \\
$\mathrm{~T}_{1}$ & 3.26 & 35.33 & 41.00 & 50.00 \\
$\mathrm{~T}_{2}$ & 3.49 & 38.33 & 45.00 & 52.33 \\
$\mathrm{~T}_{3}$ & 3.30 & 35.33 & 43.00 & 51.00 \\
$\mathrm{~T}_{4}$ & 3.86 & 42.33 & 46.33 & 54.33 \\
$\mathrm{~T}_{5}$ & 3.72 & 41.00 & 46.00 & 53.00 \\
$\mathrm{~T}_{6}$ & 3.87 & 41.67 & 46.33 & 53.67 \\
$\mathrm{~T}_{7}$ & 0.333 & 4.89 & 3.54 & 2.63 \\
\hline LSD & & $*$ & $*$ & $*$ \\
\hline $\begin{array}{l}\text { Level of } \\
\text { significance }\end{array}$ & $* *$ & 7.10 & & \\
\hline CV (\%) & 5.21 & & 4.46 & 2.83 \\
\hline
\end{tabular}

** Significant at $1 \%$ level of probability, DAT=Days after transplanting.

$\mathrm{T}_{1}=100 \% \mathrm{RDF} @ 5 \mathrm{t} / \mathrm{ha}, \mathrm{T}_{2}=50 \% \mathrm{RDF}+\mathrm{MOC} @ 1.5 \mathrm{t} / \mathrm{ha}, \mathrm{T}_{3}=50 \% \mathrm{RDF}+\mathrm{CD} @$ $10 \mathrm{t} / \mathrm{ha}, \mathrm{T}_{4}=50 \% \mathrm{RDF}+\mathrm{PM} @ 6 \mathrm{t} / \mathrm{ha}, \mathrm{T}_{5}=25 \% \mathrm{RDF}+\mathrm{MOC} @ 3 \mathrm{t} / \mathrm{ha}, \mathrm{T}_{6}=25 \% \mathrm{RDF}$ +CD@15 t/ha, $\mathrm{T}_{7}=25 \% \mathrm{RDF}+\mathrm{PM} @ 12 \mathrm{t} / \mathrm{ha}$.

\section{Head initiation}

Significant influence of different treatments on head initiation of broccoli was observed (Table 2). The plants under $\mathrm{T}_{5}$ took the longest time (42.33 days) for first head initiation which was statistically similar with $\mathrm{T}_{7}$ (41.67 days), $\mathrm{T}_{6}(41.00$ days), $T_{3}$ and $T_{1}$, while the plants of $T_{2}$ and $T_{4}$ required minimum time (35.33 days). The plants under $\mathrm{T}_{5}$ and $\mathrm{T}_{7}$ took the maximum time (46.33 days) for 50\% head initiation which was statistically similar with $T_{6}, T_{1}, T_{3}$ and $T_{4}$. On the other hand $\mathrm{T}_{2}$ took the lowest time (41.00 days) for 50\% head initiation. Again $\mathrm{T}_{5}$ took the maximum time (54.33 days) for $100 \%$ head initiation which was statistically similar with $\mathrm{T}_{7}$ (53.67 days), $\mathrm{T}_{6}$ (53.00 days), $\mathrm{T}_{1}$ and $\mathrm{T}_{3}$ and $\mathrm{T}_{2}$ took the lowest time (50.00 days) for $100 \%$ head initiation. This finding was supported by the results of Thakur et al. (1991) and Balyan et al. (1988). 


\section{Leaf size $\left(\mathrm{cm}^{2}\right)$}

Leaves size was recorded at 60 DAT. The size of leaves varied significantly due to the influence of different treatments (Table 3). The maximum leaf size (738.10 $\left.\mathrm{cm}^{2}\right)$ was found in $T_{5}$ which was identical with $T_{6}\left(732.90 \mathrm{~cm}^{2}\right)$ and $T_{7}(729.40$ $\left.\mathrm{cm}^{2}\right)$ whereas the minimum $\left(660.70 \mathrm{~cm}^{2}\right)$ was in $\mathrm{T}_{2}$.

Table 3. Effect of organic manure and inorganic fertilizer on leaf size, head diameter, head length and number of lateral headsof broccoli

\begin{tabular}{|c|c|c|c|c|}
\hline $\begin{array}{l}\text { Treatment } \\
\text { combination }\end{array}$ & $\begin{array}{l}\text { Leaf size } \\
\qquad\left(\mathrm{cm}^{2}\right)\end{array}$ & $\begin{array}{l}\text { Terminal head } \\
\text { diameter }(\mathrm{cm})\end{array}$ & $\begin{array}{l}\text { Terminal head } \\
\text { length }(\mathrm{cm})\end{array}$ & $\begin{array}{l}\text { Number of } \\
\text { lateral } \\
\text { heads/plant }\end{array}$ \\
\hline $\mathrm{T}_{1}$ & 692.20 & 14.13 & 14.33 & 4.13 \\
\hline $\mathrm{T}_{2}$ & 660.70 & 12.87 & 13.47 & 3.07 \\
\hline $\mathrm{T}_{3}$ & 681.10 & 14.20 & 13.83 & 3.60 \\
\hline $\mathrm{T}_{4}$ & 667.50 & 13.40 & 13.67 & 3.33 \\
\hline $\mathrm{T}_{5}$ & 738.10 & 16.17 & 15.57 & 4.46 \\
\hline $\mathrm{T}_{6}$ & 732.90 & 15.60 & 14.90 & 4.46 \\
\hline $\mathrm{T}_{7}$ & 729.40 & 16.17 & 15.40 & 4.86 \\
\hline $\mathrm{LSD}_{0.05}$ & 41.78 & 1.66 & 1.50 & 0.318 \\
\hline $\begin{array}{l}\text { Level of } \\
\text { significance }\end{array}$ & $* *$ & $* *$ & $*$ & $* *$ \\
\hline CV $(\%)$ & 3.35 & 6.37 & 5.85 & 4.45 \\
\hline
\end{tabular}

** Significant at $1 \%$ level of probability, DAT=Days after transplanting.

$\mathrm{T}_{1}=100 \% \mathrm{RDF} @ 5 \mathrm{t} / \mathrm{ha}, \mathrm{T}_{2}=50 \% \mathrm{RDF}+\mathrm{MOC} @ 1.5 \mathrm{t} / \mathrm{ha}, \mathrm{T}_{3}=50 \% \mathrm{RDF}+\mathrm{CD} @$ $10 \mathrm{t} / \mathrm{ha}, \mathrm{T}_{4}=50 \% \mathrm{RDF}+\mathrm{PM} @ 6 \mathrm{t} / \mathrm{ha}, \mathrm{T}_{5}=25 \% \mathrm{RDF}+\mathrm{MOC} @ 3 \mathrm{t} / \mathrm{ha}, \mathrm{T}_{6}=25 \% \mathrm{RDF}$ $+\mathrm{CD} @ 15 \mathrm{t} / \mathrm{ha}, \mathrm{T}_{7}=25 \% \mathrm{RDF}+\mathrm{PM} @ 12 \mathrm{t} / \mathrm{ha}$.

\section{Days required for terminal head harvest}

Days required for terminal head harvest varied significantly due to the influence of different treatments (Fig 1). $\mathrm{T}_{7}$ took the highest time (38 days) followed by $\mathrm{T}_{6}$ (37 days) for $1^{\text {st }}$ harvest and the lowest time was required in $\mathrm{T}_{3}$ (33.33 days). For $50 \%$ head harvest, $\mathrm{T}_{6}$ took the maximum time (50.00 days) closely followed by $\mathrm{T}_{7}$ (49.67 days) and the minimum time was $\mathrm{T}_{1}$ (44.00 days). On the other hand, for final harvest $\mathrm{T}_{7}$ took the maximum time (57.33 days) while $\mathrm{T}_{1}$ took the lowest time (49.67 days). This finding was supported by the results of Thakur et al. (1991) for cauliflower who reported that the increasing rate of $\mathrm{N}$ delayed head maturity. Balyan et al. (1988) also reported similar results in cauliflower.

\section{Diameter and length of terminal head}

Diameter and length of terminal head were significantly influenced by different treatments (Table 3). Maximum diameter was recorded in $T_{5}$ and $T_{7}(16.17 \mathrm{~cm})$ which was identical with $\mathrm{T}_{6}(15.60 \mathrm{~cm})$ and the minimum diameter $(12.87 \mathrm{~cm})$ 
was in $\mathrm{T}_{2}$. The maximum length $(15.57 \mathrm{~cm})$ of terminal head was recorded in $\mathrm{T}_{5}$ which was statistically similar to $\mathrm{T}_{7}(15.40 \mathrm{~cm}), \mathrm{T}_{6}(14.90 \mathrm{~cm})$ and $\mathrm{T}_{1}(14.33$ $\mathrm{cm})$. On the contrary minimum length $(13.47 \mathrm{~cm})$ was found in $\mathrm{T}_{2}$.

\section{Number of lateral heads/plant}

There was a significant variation in number of lateral heads produced by the plants under different treatments (Tables 3). The maximum number of lateral heads (4.86) was recorded in $\mathrm{T}_{7}$ with the minimum (3.071) of lateral heads was recorded in $\mathrm{T}_{2}$.Similar trend has also been reported by Bankder and Mukhopadhyay (1980).

\section{Weight of terminal head}

Weight of terminal head varied significantly due to the influence of different organic manures and inorganic fertilizers (Table 4). The plants of $\mathrm{T}_{7}$ produced the maximum terminal head weight $(424.60 \mathrm{~g})$ which was statistically similar to $\mathrm{T}_{5}(422.30 \mathrm{~g})$ and $\mathrm{T}_{6}(413.50 \mathrm{~g})$ while $\mathrm{T}_{2}$ produced the lowest $(328.90 \mathrm{~g})$. This result is in agreement with Kandil and Gad (2009) who concluded that using organic manure along with inorganic fertilizers gave a significant promotive effect on plant growth, head yield, chemical constituents and mineral composition of broccoli. Similar results were also reported by Chaterjee et al. (2005), Mellgren (2008) and Yoldas and Esiyok (2004) in broccoli.

Table 4.Effect of organic manure and inorganic fertilizer on terminal headweight, lateral headweight, head weight per plant, yield per plot and yieldof broccoli

\begin{tabular}{c|c|c|c|c|c}
\hline $\begin{array}{c}\text { Treatment } \\
\text { combination }\end{array}$ & $\begin{array}{c}\text { Terminal head } \\
\text { weight }(\mathrm{g})\end{array}$ & $\begin{array}{c}\text { Lateral head } \\
\text { weight }(\mathrm{g})\end{array}$ & $\begin{array}{c}\text { Head } \\
\text { weight per } \\
\text { plant }(\mathrm{g})\end{array}$ & $\begin{array}{c}\text { Yield per } \\
\text { plot(kg) }\end{array}$ & Yield(t/ha) \\
\hline $\mathrm{T}_{1}$ & 374.4 & 137.5 & 511.93 & 10.58 & 17.64 \\
$\mathrm{~T}_{2}$ & 328.9 & 120.2 & 449.10 & 8.98 & 14.97 \\
$\mathrm{~T}_{3}$ & 372.7 & 134.5 & 507.27 & 10.14 & 16.91 \\
$\mathrm{~T}_{4}$ & 339.8 & 125.8 & 452.27 & 9.31 & 15.51 \\
$\mathrm{~T}_{5}$ & 422.3 & 155.1 & 577.43 & 11.55 & 19.19 \\
$\mathrm{~T}_{6}$ & 413.5 & 153.9 & 567.47 & 11.35 & 18.92 \\
$\mathrm{~T}_{7}$ & 424.6 & 155.5 & 579.40 & 11.60 & 19.34 \\
\hline LSD 0.05 & 34.78 & 13.83 & 9.85 & 1.04 & 1.96 \\
\hline Level of & $* *$ & $* *$ & \\
significance & \multicolumn{5}{l}{$5 * 21$} \\
\hline CV\% & 5.11 & 5.54 & 5.57 & 6.29 \\
\hline
\end{tabular}

** Significant at $1 \%$ level of probability, DAT=Days after transplanting.

$\mathrm{T}_{1}=100 \% \mathrm{RDF} @ 5 \mathrm{t} / \mathrm{ha}, \mathrm{T}_{2}=50 \% \mathrm{RDF}+\mathrm{MOC} @ 1.5 \mathrm{t} / \mathrm{ha}, \mathrm{T}_{3}=50 \% \mathrm{RDF}+\mathrm{CD} @$ $10 \mathrm{t} / \mathrm{ha}, \mathrm{T}_{4}=50 \% \mathrm{RDF}+\mathrm{PM} @ 6 \mathrm{t} / \mathrm{ha}, \mathrm{T}_{5}=25 \% \mathrm{RDF}+\mathrm{MOC} @ 3 \mathrm{t} / \mathrm{ha}, \mathrm{T}_{6}=25 \% \mathrm{RDF}$ $+\mathrm{CD} @ 15 \mathrm{t} / \mathrm{ha}, \mathrm{T}_{7}=25 \% \mathrm{RDF}+\mathrm{PM} @ 12 \mathrm{t} / \mathrm{ha}$. 


\section{Lateral head weight}

Significant variation was revealed regarding lateral head weight due to the influence of different treatments (Table 4). The highest lateral head weight was found in $\mathrm{T}_{7}(155.50 \mathrm{~g})$ which was identical with $\mathrm{T}_{5}(155.10 \mathrm{~g})$ and $\mathrm{T}_{6}(153.90 \mathrm{~g})$. The lowest lateral head weight $(120.20 \mathrm{~g})$ was obtained from $\mathrm{T}_{2}$. This phenomenon might be due to continuous release of essential nutrient elements from different manures and fertilizers used. Treatment that nourished the plants properly gave the highest weight of lateral head/plant (Rabby, 2008).

\section{Head weight per plant}

The head weight/plant of broccoli varied significantly due to different treatments (Table 4). The head yield ranged from 449.10 to $579.40 \mathrm{~g} / \mathrm{plant}$. The highest head weight/plant (579.40 g) wasrecorded in $\mathrm{T}_{7}$ which was identical with $\mathrm{T}_{5}(577.43$ $\mathrm{g})$. The lowest head weight/plant (449.10 g) was found in $\mathrm{T}_{2}$.

\section{Yield per plot}

The head yield/plot of broccoli were significantly influenced by different treatments (Table 4). The maximum head yield per plot was recorded in $\mathrm{T}_{7}(11.60$ $\mathrm{kg})$ which was statistically similar to $\mathrm{T}_{5}(11.55 \mathrm{~kg})$ and $\mathrm{T}_{6}(11.35 \mathrm{~kg})$. On the other hand, the lowest head yield per plot $(8.98 \mathrm{~kg})$ was obtained from $\mathrm{T}_{2}$. These results indicated that yields per plot can be enhanced with the application of organic manure and inorganic fertilization. This result is in agreement with Kandil and Gad (2009).

Table 5. Economic analysis of production as influenced by different organic manure and inorganic fertilizers

\begin{tabular}{c|c|c|c|c|c}
\hline $\begin{array}{c}\text { Treatment } \\
\text { combination }\end{array}$ & $\begin{array}{c}\text { Marketable } \\
\text { Yield/ha } \\
(\mathrm{t} / \mathrm{ha})\end{array}$ & $\begin{array}{c}\text { Total cost of } \\
\text { production/ha } \\
(\mathrm{Tk})\end{array}$ & $\begin{array}{c}\text { Gross } \\
\text { return/ha } \\
(\mathrm{Tk})\end{array}$ & $\begin{array}{c}\text { Net } \\
\text { return/ha } \\
(\mathrm{Tk})\end{array}$ & $\begin{array}{c}\text { Benefit } \\
\text { Cost } \\
\text { Ratio } \\
(\mathrm{BCR})\end{array}$ \\
\hline $\mathrm{T}_{1}$ & 17.64 & 125297 & 441000.00 & 315703.00 & 3.52 \\
$\mathrm{~T}_{2}$ & 14.97 & 158919 & 374250.00 & 215331.00 & 2.35 \\
$\mathrm{~T}_{3}$ & 16.91 & 130053 & 422750.00 & 292697.00 & 3.25 \\
$\mathrm{~T}_{4}$ & 15.51 & 115553 & 387750.00 & 272197.00 & 3.35 \\
$\mathrm{~T}_{5}$ & 19.19 & 223160 & 479750.00 & 256590.00 & 2.15 \\
$\mathrm{~T}_{6}$ & 18.92 & 146630 & 473000.00 & 326370.00 & 3.23 \\
$\mathrm{~T}_{7}$ & 19.34 & 132924 & 483500.00 & 350576.00 & 3.64 \\
\hline
\end{tabular}

$\mathrm{T}_{1}=100 \% \mathrm{RDF} @ 5 \mathrm{t} / \mathrm{ha}, \mathrm{T}_{2}=50 \% \mathrm{RDF}+\mathrm{MOC} @ 1.5 \mathrm{t} / \mathrm{ha}, \mathrm{T}_{3}=50 \% \mathrm{RDF}+\mathrm{CD} @$ $10 \mathrm{t} / \mathrm{ha}, \mathrm{T}_{4}=50 \% \mathrm{RDF}+\mathrm{PM} @ 6 \mathrm{t} / \mathrm{ha}, \mathrm{T}_{5}=25 \% \mathrm{RDF}+\mathrm{MOC} @ 3 \mathrm{t} / \mathrm{ha}, \mathrm{T}_{6}=25 \% \mathrm{RDF}$ +CD@15 t/ha, $\mathrm{T}_{7}=25 \% \mathrm{RDF}+\mathrm{PM} @ 12 \mathrm{t} / \mathrm{ha}$. 


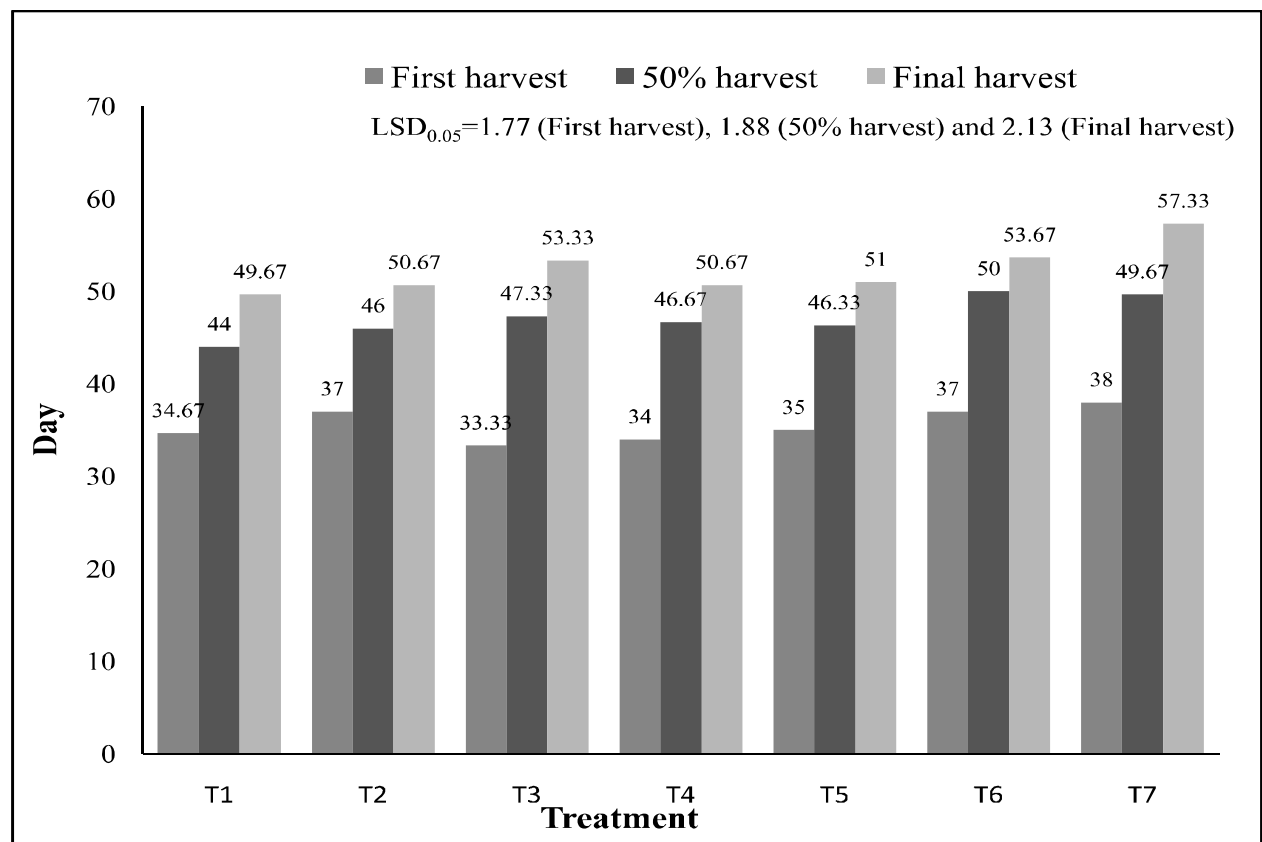

Fig. 1. Effect of organic manure and inorganic fertilizers on days required for head harvest.

$\mathrm{T}_{1}=100 \% \mathrm{RDF} @ 5 \mathrm{t} / \mathrm{ha}, \mathrm{T}_{2}=50 \% \mathrm{RDF}+\mathrm{MOC} @ 1.5 \mathrm{t} / \mathrm{ha}, \mathrm{T}_{3}=50 \% \mathrm{RDF}+\mathrm{CD} @$ $10 \mathrm{t} / \mathrm{ha}, \mathrm{T}_{4}=50 \% \mathrm{RDF}+\mathrm{PM} @ 6 \mathrm{t} / \mathrm{ha}, \mathrm{T}_{5}=25 \% \mathrm{RDF}+\mathrm{MOC} @ 3 \mathrm{t} / \mathrm{ha}, \mathrm{T}_{6}=25 \% \mathrm{RDF}$ $+\mathrm{CD} @ 15 \mathrm{t} / \mathrm{ha}, \mathrm{T}_{7}=25 \% \mathrm{RDF}+\mathrm{PM} @ 12 \mathrm{t} / \mathrm{ha}$

\section{Yield per hectare}

Yield per hectare was also significantly influenced by different treatment combination (Table 4). The highest head yield per hectare $(19.34 \mathrm{t} / \mathrm{ha})$ was recorded from $\mathrm{T}_{7}$ which was identical with $\mathrm{T}_{5}(19.19 \mathrm{t} / \mathrm{ha}), \mathrm{T}_{6}(18.92 \mathrm{t} / \mathrm{ha})$ and $\mathrm{T}_{1}$ (17.64 $\mathrm{t} / \mathrm{ha}$ ) while the lowest head yield of $14.97 \mathrm{t} / \mathrm{ha}$ was recorded in $\mathrm{T}_{2}$.Similar results were reported by Chaterjee et al. (2005).

\section{Economic analysis}

The production cost of broccoli varied due to different organic manure and inorganic fertilizers (Table 5). Cost of production was higher in other approaches compared to recommended approach. Production cost was the highest (Tk. 223160/ha) in $\mathrm{T}_{5}$ followed by $\mathrm{T}_{2}$ (Tk. 158919/ha) and it was the lowest (Tk. 115553/ha) in $\mathrm{T}_{4}$. The maximum gross return (Tk. 483500.00/ha) and net return (Tk. 350576.00/ha) were found in $\mathrm{T}_{7}$ while the minimum in $\mathrm{T}_{2}$ (Tk. 374250.00/ha and 215331.00/ha, respectively). The highest benefit cost ratio (3.64) was found in $T_{7}$ followed by $T_{1}$ (3.52) while it was the lowest in $T_{5}$ (2.15). 


\section{Conclusion}

Based on the results of the present study,it can be concluded that the treatment $\mathrm{T}_{7}=(25 \% \mathrm{RDF}+\mathrm{PM} @ 12 \mathrm{t} / \mathrm{ha})$ performed the best regarding diameter of stem, terminal headdiameter, length of terminal head, terminal headweight per plant, no. of lateral heads per plant, weight of lateral heads per plant, yield per plot and yield per hectare (t/ha). Thistreatment was statistically similar to $\mathrm{T}_{5}(25 \% \mathrm{RDF}+$ MOC @ $3 \mathrm{t} / \mathrm{ha}$ ).Gross return and net return was the highest in $\mathrm{T}_{7}$ and benefit cost ratio was also the maximum (3.64) in the same treatment. Hence, 25\% RDF + PM@ 12 t/ha may be the recommended for sustainable broccoli production.

\section{References}

Abou El- Magd, M.M., A.M, El-Bassiony and Z.F. Fawzy. 2006. Effect of Organic Manure with or Without Chemical Fertilizers on Growth, Yield and Quality of Some Varieties of Broccoli Plants. JApplied Sci Res. 2(10): 791-798.

Akter, S., S. Noor, M. Rahman, S. Sultana and S. K. Nandi. 2012. Effect of orgnaic manure and chemical fertilizer on the yield of broccoli. Bangladesh Hort. 24(1\&2): 59-64.

Attigah, A.S., Asiedu, E.K., Agyarko, K. and Dapaah, H.K. 2013. Growth and yield of okra (Abelmoschus esculentus L.) as affected by organic and inorganic fertilizers. ARPN: J. Agri. Biol. Sci. 8(12):766-770.

Balyan, D. S., B. S. Dhankar, D. S. Ruhul and K. P. Singh. 1988. Growth and yield of cauliflower variety Snowball-16 as influenced by nitrogen, phosphorus and zinc. Haryana. J. Hort. Sci. 17: 247-254.

Bankder, G. J, and A, Mukhopadhay. 1980. Response of Polianthes tuberose L. to high doses of mineral nutrition. S. Indian Hort. 33: 214-216.

Chaterjee, B., P. Ghanti, U. Thapa and P. Tripathy. 2005. Effect of organic nutrition in sprout broccoli (Brassica aleraceae var. italica), Vegetable Science. 33 (1): 51-54.

Gomez, K. A. and A. A. Gomez. 1984. Statistical Procedures for Agricultural Research. John Wiley and Sons Publication. New York. Pp. 202-215.

Kandil, H. and N. Gad. 2009. Effects of inorganic and organic fertilizers on growth and production of brocoli (Brassica oleracea L.). Factoti si Procese Pedogenetice din Zona Temperata 8 S. noua (2009) 61-69.

Kumar, M., B.Das, K.K. Prasad, and P. Kumar. 2013. Effect of integrated nutrient management on growth and yield of broccoli (Brassica oleracea var. italica) under Jharkhand conditions. Veg. Sci., 40(1): 117-120.

Mellgren, R. 2008. Effect of irrigation and nitrogen treatments on yield, quality, plant nitrogen uptake and soil nitrogen status and the evaluation of sap test, SPAD chlorophyll meter and Dualex to monitor nitrogen status in broccoli. Master thesis in the Horticultural Science Programme. Agriculture and Agri-Food Canada's L'Acadie research substation.

Mital, R.K., T. Singh., M. Bhugat and K. P. Maheshwari. 1975. Response of broccoli to nitrogen and row spacing. Indian J. Agronomy. 20(3): 278-279. 
Rabby, F. M., 2008. Study on growth, yield and quality of broccoli (Brassica aleracea var. italica L) under organic farming, an unpublished MS thesis, Department of Horticulture, Bangabandhu Sheikh Mujibur Rahman Agricultural University, Salna, Gazipur -1706.

Rakesh, S., S. N. S. Chaurasia and S. N. Singh. 2006. Response of nitrogen sources and spacing on growth and yield of broccoli (Brassica aleracea var. italica plenck), Vegetable Sci. 33(2): 198- 200.

Singh, R. D, S. N. Tiwari, B. B. Singh and J. N. Seth. 1976. Effect of nitrogen and potash on growth and curd yield of cauliflower variety Snowball-16. Prog. Hort. 7(4): 3134.

Swarup, V. 2012. Vegetable science and technology in India. Kalayani Publishers, New Delhi, Pp. 370-371.

Thakur, O. P., P. P. Sharma and K. K. Singh. 1991. Effect of nitrogen and phosphorus with and without boron on head yield and stalk-rot incidence in cauliflower. Vegetable Sc. 18: 115-121.

Thompson, H.C. and W.C.Kelly. 1988. Vegetable crops. Fifth edition, Tata Mc Graw Hill Book Co. New York, Tornoto, London. P: 307.

Yoldas, F. and D. Esiyok. 2004. Effects of plant spacing, sowing and planting date on yield and some quality parameters of broccoli. Ege University, Turkey. 41(2): 37-48. 
Appendix 1a. Physical properties of soil of the experimental field (0-15 cm)

\begin{tabular}{lc}
\hline Physical Properties & Content \\
\hline Sand $(\%)$ & 21.2 \\
Silt $(\%)$ & 51.4 \\
Clay $(\%)$ & 27.4 \\
Bulk density $\left(\mathrm{g} / \mathrm{cm}^{3}\right)$ & 1.36 \\
Particle density $\left(\mathrm{g} / \mathrm{cm}^{3}\right)$ & 2.65 \\
Soil porosity $(\%)$ & 51.32 \\
Textural class & Silt loam
\end{tabular}

Appendix 1b. Chemical properties of soil of the experimental field $(0-15 \mathrm{~cm})$

\begin{tabular}{lc|c|c}
\hline \multicolumn{1}{c|}{ Chemical Properties } & $\begin{array}{c}\text { Analytical } \\
\text { value }\end{array}$ & $\begin{array}{c}\text { Critical } \\
\text { value }\end{array}$ & $\begin{array}{c}\text { Optimum } \\
\text { value }\end{array}$ \\
\hline $\mathrm{P}^{\mathrm{H}}$ & 6.1 & - & - \\
Organic Carbon (\%) & 0.82 & - & - \\
Total N (\%) & 0.118 & 0.075 & 3.0 \\
Available phosphorus (ppm) & 14.185 & 14.0 & 60.0 \\
Exchangeable Potassium (meq/100g) & 0.475 & 0.2 & 1.5 \\
Exchangeable Calcium (meq/100g) & 8.5 & 2.0 & 18.0 \\
Exchangeable Magnesium (meq/100g) & 2.035 & 0.8 & 9.0 \\
Available Sulphur (ppm) & 15.23 & 14.0 & 60.0 \\
\hline
\end{tabular}

$\mathrm{CEC}(\mathrm{meq} / 100 \mathrm{~g})=20.55$

Appendix 2. Nutrient content $(\%)$ of cowdung, mustard oil cake and poultry manure

\begin{tabular}{l|c|c|c}
\hline \multirow{1}{*}{ Organic manure } & \multicolumn{3}{|c}{ Nutrient content (\%) } \\
\cline { 2 - 4 } & $\mathrm{N}$ & $\mathrm{P}$ & $\mathrm{K}$ \\
\hline Cowdung & 0.45 & 0.15 & 0.45 \\
Mustard oil cake & 4.8 & 1.6 & 1.2 \\
Poultry manure & 1.89 & 0.55 & 0.73 \\
\hline
\end{tabular}


Appendix 3. Monthly record of temperature, relative humidity and rainfall during the period from September, 2015 to February, 2016

\begin{tabular}{|c|c|c|c|c|c|c|}
\hline \multirow{2}{*}{ Year } & \multirow{2}{*}{ Month } & \multicolumn{3}{|c|}{$* *$ Air temperature $\left({ }^{\mathrm{O}} \mathrm{C}\right)$} & \multirow{2}{*}{$\begin{array}{c}* * \text { Relative } \\
\text { humidity } \\
(\%)\end{array}$} & \multirow{2}{*}{$\begin{array}{c}* \text { Rainfall } \\
\quad(\mathrm{mm})\end{array}$} \\
\hline & & Maximum & Minimum & Average & & \\
\hline \multirow{4}{*}{2015} & September & 33.03 & 26.56 & 29.80 & 86.60 & 253.18 \\
\hline & October & 32.91 & 23.38 & 28.15 & 85.74 & 22.05 \\
\hline & November & 30.45 & 18.31 & 24.38 & 85.33 & 0.00 \\
\hline & December & 25.96 & 13.93 & 19.95 & 88.61 & 0.00 \\
\hline \multirow[b]{2}{*}{2016} & January & 24.24 & 12.82 & 18.53 & 85.03 & 12.98 \\
\hline & February & 27.14 & 14.92 & 21.03 & 75.96 & 3.89 \\
\hline
\end{tabular}

* Monthly total

** Monthly average

Source: Weather Records of Bangabandhu Sheikh Mujibur Rahman Agricultural University, Gazipur-1706, Bangladesh.

Appendix 4. Date of head initiation and head harvest of broccoli

\begin{tabular}{|c|c|c|c|c|c|c|}
\hline \multirow[b]{2}{*}{ Treatment } & \multicolumn{3}{|c|}{ Date of head initiation } & \multicolumn{3}{|c|}{ Date of head harvest } \\
\hline & $\begin{array}{l}1^{\text {st }} \text { head } \\
\text { initiation }\end{array}$ & $\begin{array}{l}50 \% \text { head } \\
\text { initiation }\end{array}$ & $\begin{array}{l}100 \% \text { head } \\
\text { initiation }\end{array}$ & $\begin{array}{l}1^{\text {st }} \text { head } \\
\text { initiation }\end{array}$ & $\begin{array}{l}50 \% \text { head } \\
\text { initiation }\end{array}$ & $\begin{array}{l}100 \% \text { head } \\
\text { initiation }\end{array}$ \\
\hline $\mathrm{T}_{1}$ & $30 / 12 / 2015$ & 07/01/2016 & $14 / 01 / 2016$ & $03 / 02 / 2016$ & $13 / 02 / 2016$ & $18 / 02 / 2016$ \\
\hline $\mathrm{T}_{2}$ & $28 / 12 / 2015$ & 03/01/2016 & $18 / 01 / 2016$ & $03 / 02 / 2016$ & $16 / 02 / 2016$ & $20 / 02 / 2016$ \\
\hline $\mathrm{T}_{3}$ & $31 / 12 / 2015$ & $07 / 01 / 2016$ & $14 / 01 / 2016$ & $02 / 02 / 2016$ & $16 / 02 / 2016$ & $22 / 02 / 2016$ \\
\hline $\mathrm{T}_{4}$ & $28 / 12 / 2015$ & 05/01/2016 & $13 / 01 / 2016$ & $01 / 02 / 2016$ & $13 / 02 / 2016$ & $19 / 02 / 2016$ \\
\hline $\mathrm{T}_{5}$ & $04 / 01 / 2016$ & 08/01/2016 & $16 / 01 / 2016$ & 02/02 2016 & $13 / 02 / 2016$ & $20 / 02 / 2016$ \\
\hline $\mathrm{T}_{6}$ & 03/01/2016 & 08/01/2016 & $15 / 01 / 2016$ & $09 / 02 / 2016$ & 28/01/2016 & $02 / 03 / 2016$ \\
\hline $\mathrm{T}_{7}$ & 03/01/2016 & $08 / 01 / 2016$ & $15 / 01 / 2016$ & $09 / 02 / 2016$ & $20 / 02 / 2016$ & $28 / 02 / 2016$ \\
\hline
\end{tabular}




\begin{tabular}{|c|c|c|}
\hline & $1500[\mathrm{ElO} L$ & 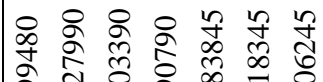 \\
\hline & 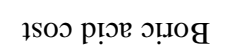 & 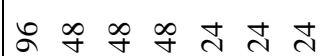 \\
\hline & $1 \mathrm{~s} 0 \mathrm{o}^{\dagger} \mathrm{OSUZ}$ & 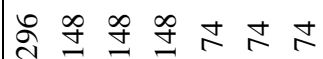 \\
\hline & ¡soo unsd $\kappa$ & 号号号へ \\
\hline & $1500 \quad \mathrm{~d} O \mathrm{~N}$ & 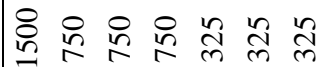 \\
\hline & ¡s00 dSL & 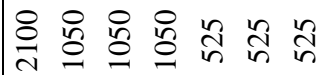 \\
\hline & ұsоว вә. & 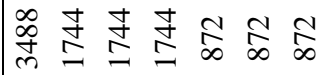 \\
\hline & ¡soo Wd & 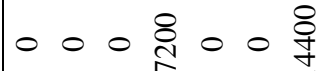 \\
\hline & 1so0 $\mathrm{DON}$ & 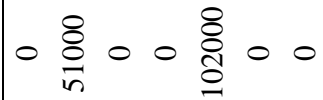 \\
\hline & बว & 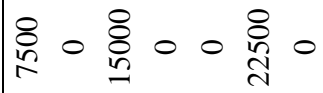 \\
\hline & $\begin{array}{c}\text { səp!̣!ôuny } \\
\text { pursəp!ฺ̣̣วsuI }\end{array}$ & 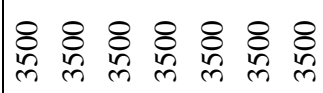 \\
\hline & 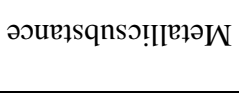 & \& \& \& \& \& \& \\
\hline & 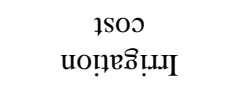 & 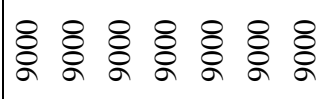 \\
\hline & џ̣вчо ривооqшея & ¿ \& \\
\hline & ұsoo pəəs & 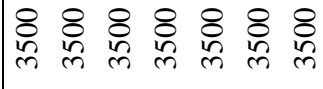 \\
\hline & 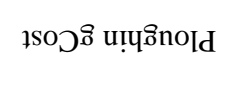 & 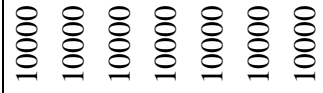 \\
\hline & 1soo .noqe T & 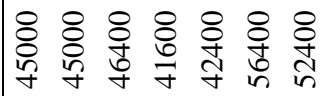 \\
\hline & 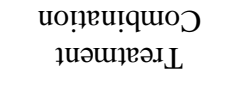 & \\
\hline
\end{tabular}

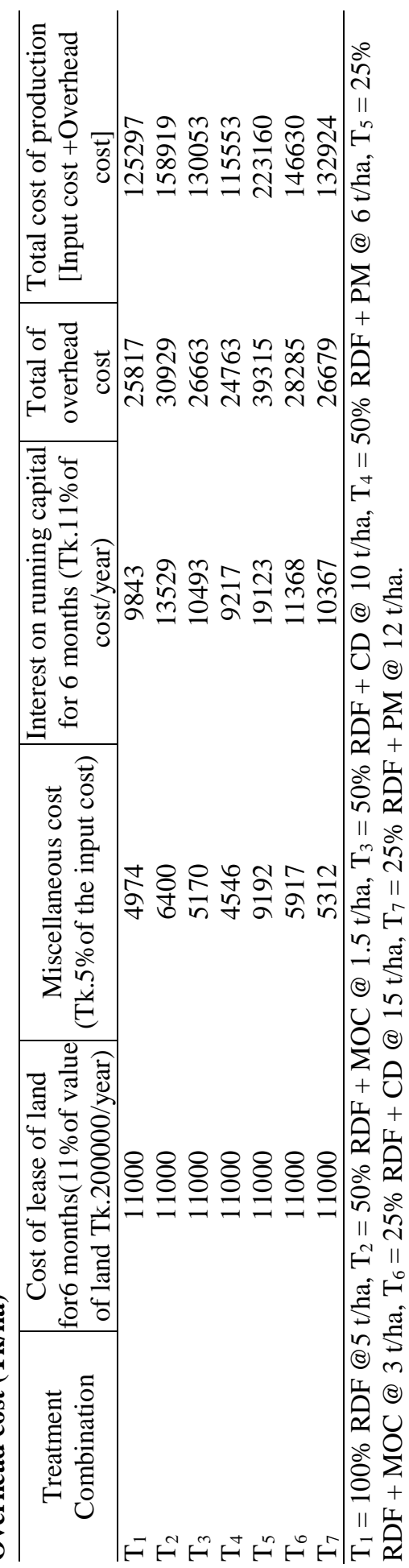

